\title{
Exogenous Applications of Abscisic Acid Increase Curing of Pierce's Disease-Affected Grapevines Growing in Pots
}

\author{
Melody M. Meyer and Bruce C. Kirkpatrick, Department of Plant Pathology, University of California, Davis
}

\begin{abstract}
Meyer, M. M., and Kirkpatrick, B. C. 2011. Exogenous applications of abscisic acid increase curing of Pierce's disease-affected grapevines growing in pots. Plant Dis. 95:173-177.

Foliar and drench applications of the plant growth regulator abscisic acid (ABA) were applied to 1-year-old potted Vitis vinifera 'Pinot Noir' and 'Cabernet Sauvignon' vines infected with Xylella fastidiosa, the bacterial pathogen that causes Pierce's disease (PD). A naturally occurring ABA and a synthetic ABA were applied, and both materials showed some effectiveness at increasing curing rates of PD-affected

grapevines. Pinot Noir grapevines treated with the drench ABA treatments had significantly greater disease curing effects than the unsprayed control plants. It has been shown that plant phenolics have antimicrobial properties, and we found a positive correlation between effective ABA treatments and the total phenolic compound content of xylem sap extracted from Pinot Noir vines.
\end{abstract}

Xylella fastidiosa is a xylem-limited, gram-negative bacterium that causes Pierce's disease (PD) in grapevines and scorch diseases in plant hosts belonging to more than 28 plant families $(11,19,20,35,37)$. The bacteria colonize and occlude xylem vessels and disrupt water flow in the plant $(12,19,29)$. Foliar symptoms typically appear 3 to 5 months after infection in the spring. Longterm effects of $X$. fastidiosa infection and PD symptom development include reduced fruit production, root system decline, dwarfing of plants, and eventual death of the grapevine $(1,21,37)$. Differences in climate, environment (temperatures, water, and soil), stress (diseases, drought, and fruit overproduction), and grape cultivar can affect the onset and severity of symptoms $(19,22$, 28,29,36).

$\mathrm{PD}$ is currently found in many regions of California and the southeastern United States. One factor shown to be associated with the observed limited geographical distribution of PD in North America is the severity of winter temperatures in those regions (21). Purcell $(33,34)$ demonstrated that relatively brief exposures to subfreezing temperatures eliminated X. fastidiosa in Vitis vinifera grapevines. More recently, Purcell's group demonstrated that intact, $X$. fastidiosa-infected potted vines exposed to low temperatures had a higher rate of recovery than PD-affected detached stem segments exposed to the same cold temperatures (9). This suggests that factors expressed in the intact plant but not in detached stem segments helped to eliminate $X$. fastidiosa from the infected plants.

Abscisic acid (ABA) is a plant hormone that is produced by nearly all plants. It is synthesized in most photosynthetic tissues, and $\mathrm{ABA}$ synthesized in the roots can be translocated in the xylem to aerial portions of a plant. ABA produced by water-stressed roots is translocated in the xylem (47) to leaves, where it rapidly reduces the osmotic potential of guard cells, causing them to lose turgor, stomates to close, and transpiration to greatly reduce, thus helping a plant survive water stress conditions. ABA is also a key factor is causing and maintaining plant and seed dormancy and slowing plant growth (48). ABA also plays important roles in mediating plant disease responses, as reviewed by Bostock $(2,3)$.

Corresponding author: B. C. Kirkpatrick

E-mail: bckirkpatrick@ucdavis.edu

Accepted for publication 13 September 2010.

doi:10.1094/PDIS-06-10-0446

(C) 2011 The American Phytopathological Society
Previous research has shown that herbaceous and woody plants exposed to sublethal cold temperatures exhibit significantly elevated levels of plant hormones, such as ABA, which induce the synthesis of a number of cold-shock proteins $(4,6,14,44)$. During cold acclimation, several pathogenesis-related (PR) proteins such as chitinase, $\beta$-1,3-glucanase, and thaumatin-like protein (TLP) are secreted into the apoplast $(6,16,43)$.

Chen et al. (5) documented increased ABA levels during cold acclimation and showed that exogenous applications of ABA enhanced freezing tolerance and elicited cold-inducible proteins in plants that are able to cold acclimate. ABA was also shown to have an effect on the amount of total phenolics in some plants. Exogenous ABA applied to harvested fruit caused increases in fruit phenolic content $(23,25)$. Several phenolic compounds have been shown to have antimicrobial properties $(8,27,32,38-40)$.

The goal of this research was to determine the effect of treating PD-affected grapevines with ABA, assess its effect on phenolic compound concentrations in grapevine xylem sap, and evaluate ABA applications as a possible therapy for PD.

\section{Materials and Methods}

Plant materials. Rooted V. vinifera 'Pinot Noir' (PD susceptible; 36), 'Cabernet Sauvignon' (less susceptible to PD; 36), and 'Chardonnay' (PD susceptible; 36) (tested 2007-08 only), grapevines grafted onto 101-14 rootstock were obtained from Sunridge Nursery, CA and grown in 1-gal. pots in a greenhouse. The irrigation regime was supplemented with half-strength Hoagland's solution. New plants were used for each year of the 3-year study.

Inoculation with $X$. fastidiosa. Inoculum was prepared using $X$. fastidiosa 'Stag's Leap' (American Type Culture Collection no. 700963). Bacteria from 7- to 11-day-old cultures grown on PD3 medium (7) were suspended in sterile deionized water to a concentration of approximately $10^{8} \mathrm{CFU} / \mathrm{ml}$. Grapevines were inoculated in mid-May using a pinprick inoculation procedure $(15,17,35)$. Control vines were inoculated with water. During late summer and fall, the plants were moved into a screenhouse in order to acclimatize them to decreasing temperatures. Twelve weeks after inoculation, the plants were rated for disease using a symptom severity index of 0 (healthy) to 5 (dead) (13). X. fastidiosa inoculated plants were tested with immunocapture polymerase chain reaction (ICPCR) (42) to confirm the presence of $X$. fastidiosa. The temperatures during the treatment periods were measured by the CIMIS weather station in Davis, CA.

IC-PCR analysis. Smart et al. (42) determined that IC-PCR was one of the most sensitive and reliable methods of detecting $X$. fastidiosa in plant tissue, and we used a modification of that IC-PCR 
protocol for detecting $X$. fastidiosa in this study. Approximately 0.7 $\mathrm{g}$ of petiole tissue from symptomatic infected grapevines was mixed with $3 \mathrm{ml}$ of modified SCP buffer $(1.0 \mathrm{~g}$ of sodium succinate, $1.0 \mathrm{~g}$ of trisodium citrate, $1.5 \mathrm{~g}$ of $\mathrm{K}_{2} \mathrm{HPO}_{4}, 1.0 \mathrm{~g}$ of $\mathrm{KH}_{2} \mathrm{PO}_{4}$, and $50.0 \mathrm{~g}$ of PVP-40 were added to 1 liter of water). Ascorbic acid was added to a final concentration of $0.02 \mathrm{M}$ just prior to use and the $\mathrm{pH}$ adjusted to 7.4 with $1 \mathrm{M} \mathrm{NaOH}$. The tissue was placed in a grinder bag (Bio-Rad), and ground for approximately 10 to 15 $\mathrm{s}$ in a Lenze roller device (Bioreba AG, Switzerland). A portion of the liquid grindate was transferred to a $1.5-\mathrm{ml}$ microcentrifuge tube and centrifuged at $16,000 \times g$ for $5 \mathrm{~min}$. The supernatant was discarded and the pellet was resuspended in $500 \mu \mathrm{l}$ of $1 \times$ phosphatebuffered saline (PBS) containing $1 \%$ bovine serum albumin (BSA). Anti- $X$. fastidiosa rabbit antiserum (100 $\mu$ liluted $1 / 1000$ in PBS/BSA) was added to the plant suspensions. The sample was incubated at room temperature for $30 \mathrm{~min}$ with gentle shaking and then centrifuged at $16,000 \times g$ for $2.5 \mathrm{~min}$. The supernatant was discarded and the pellet was resuspended in $1 \mathrm{ml}$ of PBS/BSA. Sheep anti-rabbit antibody coated beads $(5 \mu \mathrm{l}$; DYNA beads; Invitrogen) were added and incubated at room temperature for $30 \mathrm{~min}$ with gentle shaking. The beads, captured with a DYNAL magnet, were washed three times with 1,1 , and $0.5 \mathrm{ml}$ of PBS/BSA buffer, respectively. The beads were resuspended in $10 \mu \mathrm{l}$ of sterile distilled water. Then, $5 \mu \mathrm{l}$ of beads were placed into a $0.5-\mathrm{ml}$ PCR tube, and $25 \mu \mathrm{l}$ of PCR cocktail containing $12.8 \mu \mathrm{l}$ of deionized water, $3.0 \mu \mathrm{l}$ of $1.5 \mathrm{mM}$ dNTP, $3.0 \mu \mathrm{l}$ of PCR buffer, $3.0 \mu \mathrm{l}$ of $5 \mu \mathrm{M}$ of RST31, and $3.0 \mu \mathrm{l}$ of $5 \mu \mathrm{M}$ RST33, X. fastidiosa-specific primers (31), and $1 \mathrm{U}$ of Taq were added for each sample. The PCR was performed at $95^{\circ} \mathrm{C}$ for $5 \mathrm{~min}$ (initial denaturation); followed by $95^{\circ} \mathrm{C}$ for $30 \mathrm{~s}, 55^{\circ} \mathrm{C}$ for $30 \mathrm{~s}$, and $72^{\circ} \mathrm{C}$ for $45 \mathrm{~s}$ for 35 cycles; and a final extension at $72^{\circ} \mathrm{C}$ for $10 \mathrm{~min}$. PCR products were analyzed by agarose gel electrophoresis and gels were stained with ethidium bromide.
ABA applications. When the grapevines were going dormant but still had attached leaves in early November of each experimental year (2005, 2006, and 2007), foliar sprays or soil drenches of ABA solutions were applied to healthy and $X$. fastidiosa-infected Cabernet Sauvignon, Pinot Noir, and Chardonnay (2007-08 only) vines. Two ABA compounds were provided by Valent Biosciences Corporation. One was a naturally occurring ABA (VBC-30054) that has a comparatively short persistence time (12 to $24 \mathrm{~h})$ and is UV sensitive. The synthetic ABA (VBC-30030) has a greater persistence time of 24 to $36 \mathrm{~h}$ and was less light sensitive. Each ABA powder was dissolved in $99 \%$ ethanol to generate a 100,000 ppm stock solution. ABA stock solutions were diluted to the desired concentration using deionized water. Tween 20 was added to foliar spray solutions to a final concentration of $0.05 \%$. ABA treatments applied to grapevines (approximately $200 \mathrm{ml}$ of ABA solution per plant) were based on recommendations from Valent Biosciences (Table 1). Unfortunately, at least $1 \mathrm{~cm}$ of rain fell in the evening of the day that ABA was applied in 2006-07. Resulting differences in rates of PD curing for treated and untreated vines were not as pronounced as in the other 2 years of the study and we suspect that the rain event diluted or washed off the applied ABA.

To determine the effect of natural and synthetic ABA treatments on occurrence and severity of PD, vines were evaluated for PD symptoms and tested by IC-PCR in September, 10 months after ABA application. These treatments were repeated three times over a 3-year time period. Each year, 16 X. fastidiosa-inoculated and 16 healthy grapevines of each cultivar were used as controls to compare the effect of ABA treatments on PD recovery.

Xylem sap extraction and testing. In 2007, 4 days after ABA applications, 10 grapevines of each treatment (described above) were cut and the top three-fourths of the cane was removed and transported to the lab. Xylem sap from each cane was extracted using a custom made pressure bomb (PMS Instrument Company,

Table 1. Abscisic acid treatments for the 3 years of the study

\begin{tabular}{|c|c|c|c|c|c|}
\hline \multirow[b]{2}{*}{ Year } & \multirow[b]{2}{*}{ Control } & \multicolumn{2}{|c|}{ VBC-30054 } & \multicolumn{2}{|c|}{ VBC-30030 } \\
\hline & & 2,000 ppm spray & 100 ppm drench & 100 ppm spray & $10 \mathrm{ppm}$ drench \\
\hline 2005 & $\mathrm{X}$ & $\mathrm{X}$ & $\mathrm{X}$ & $X$ & $\mathrm{X}$ \\
\hline 2006 & $\mathrm{X}$ & $\mathrm{X}$ & $\mathrm{X}$ & & $\mathrm{X}$ \\
\hline 2007 & $X$ & $\mathrm{X}$ & $X$ & $X$ & $X$ \\
\hline
\end{tabular}

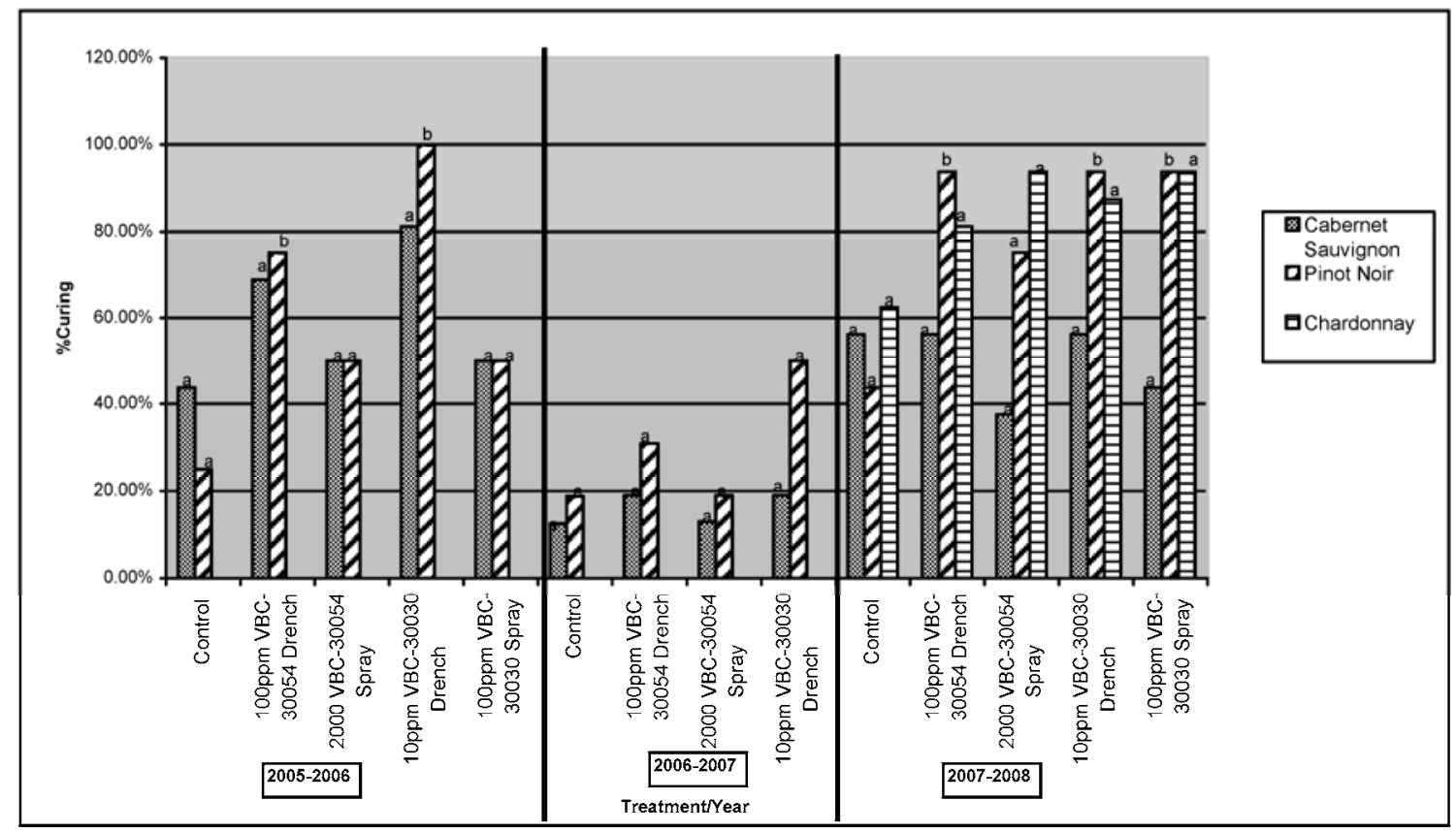

Fig. 1. Percentage of previously confirmed Xylella fastidiosa-positive plants that tested $X$. fastidiosa negative by immunocapture polymerase chain reaction the season following abscisic acid treatments. Each year and cultivar was analyzed separately. Significant by Fisher's test at $P$ value $=0.05$. 
Albany, OR). The concentration of total phenolic compounds in each xylem sap sample was determined using the Folins-Ciocalteu procedure $(41,46)$

\section{Results}

ABA curing of $\boldsymbol{X}$. fastidios $\boldsymbol{a}$-infected grapevines. Several ABA applications had a significant curing effect on $X$. fastidiosainfected $V$. vinifera Pinot Noir and Cabernet Sauvignon grapevines (Fig. 1). In the 2005-06, season the most effective treatment was the $10 \mathrm{ppm}$ VBC-30030, the more active and stable ABA drench treatment which resulted in $100 \%$ curing in Pinot Noir and $81 \%$ curing in Cabernet Sauvignon. In Pinot Noir vines, 100 ppm VBC30054, which was chemically identical to naturally occurring ABA and less active and stable than VBC-30030, produced significantly more curing than control vines. In 2006-07, none of the treatments were significantly different from the control, possibly due to a rain event that occurred within a few hours of the ABA application. In the 2007-08 season, the $100 \mathrm{ppm}$ VBC-30054 drench treatment, the $10 \mathrm{ppm}$ VBC-30030 drench, and the $100 \mathrm{ppm}$ VBC-30030 spray had significantly greater curing than the nontreated control in Pinot Noir grapevines.

A variable amount of natural cold curing occurs in Davis, depending upon the number of chilling hours. Temperature data were collected each hour during the treatment period (1 November to 15 March). Degree hours were calculated by recording the number of degrees below the threshold set temperature $\left(0\right.$ and $\left.-5^{\circ} \mathrm{C}\right)$ at each recording time point. These values were summed for a total number of degree hours for each year of the study (Table 2). Based on the numbers of hours below 0 and $-5^{\circ} \mathrm{C}$, the greatest number of cold chilling hours occurred in 2006-07, followed by 2007-08 and 200506. Because of the impact of the rain event following ABA application in 2006-07, reasonable comparisons can only be made between 2007-08 and 2005-06. Examining the percentages of curing that occurred in those 2 years, these was a positive association between the lower temperatures in 2007-08 and higher rates of PD curing.

PD disease severity ratings for $\mathrm{ABA}$-treated grapevines. Disease severity ratings for the $10 \mathrm{ppm}$ VBC-30030 drench treatment, for all 3 years were significantly less in both Pinot Noir and Cabernet Sauvignon grapevines than the controls (Fig. 2). In the first year (2005-06), the $10 \mathrm{ppm}$ VBC-30030 drench treatment had significantly lower ratings than the control. In the second year (2006-07), the $100 \mathrm{ppm}$ VBC-30054 drench- and the $10 \mathrm{ppm}$ VBC-30030 drench-treated Pinot Noir plants had significantly lower disease ratings than the controls; the 10 ppm VBC-30030 drench treatment of Cabernet Sauvignon was also significantly lower than the controls. In the third year (2007-08), the 100 ppm VBC-30054 drench, the $2000 \mathrm{ppm}$ VBC-30054 spray, the $10 \mathrm{ppm}$ VBC-30030 drench, and the 100 ppm VBC-30030 spray treatment were significantly lower than the controls for Pinot Noir vines, whereas the $10 \mathrm{ppm}$ VBC-30030 drench and the $100 \mathrm{ppm}$ VBC30054 spray treatments had significant lower disease severity ratings than the control for Cabernet Sauvignon vines.

Total phenolic content of xylem sap from ABA treated grapevines. The total phenolic content of xylem sap extracted from several ABA treatments showed significantly elevated levels compared with untreated controls (Fig. 3). In Pinot Noir vines, the 10 ppm VBC30030 drench treatment, the 100 ppm VBC-30030 spray treatment, and 2,000 ppm VBC-30054 spray treatment had significantly higher total phenolic content in extracted xylem sap than the unsprayed control vines. In the Cabernet Sauvignon vines, the total phenolic content of the 100 ppm VBC-30054 drench-treated vines was significantly yet unexpectedly lower than the control (Fig. 3).

\section{Discussion}

It has been shown that increased environmental stresses such as drought, heat, and so on can cause increased levels of ABA, which

Table 2. Calculated degree hours below 0 and $-5^{\circ} \mathrm{C}$ for over the 3 years of the experiment at the CIMIS weather station in Davis, CA

\begin{tabular}{|c|c|c|c|c|c|}
\hline \multicolumn{3}{|c|}{$\mathbf{0}^{\circ} \mathbf{C}$} & \multicolumn{3}{|c|}{$-5^{\circ} \mathrm{C}$} \\
\hline 2005-06 & $2006-07$ & $2007-08$ & $2005-06$ & 2006-07 & $2007-08$ \\
\hline 34.3 & 211.0 & 53.1 & 0 & 3.9 & 0 \\
\hline
\end{tabular}

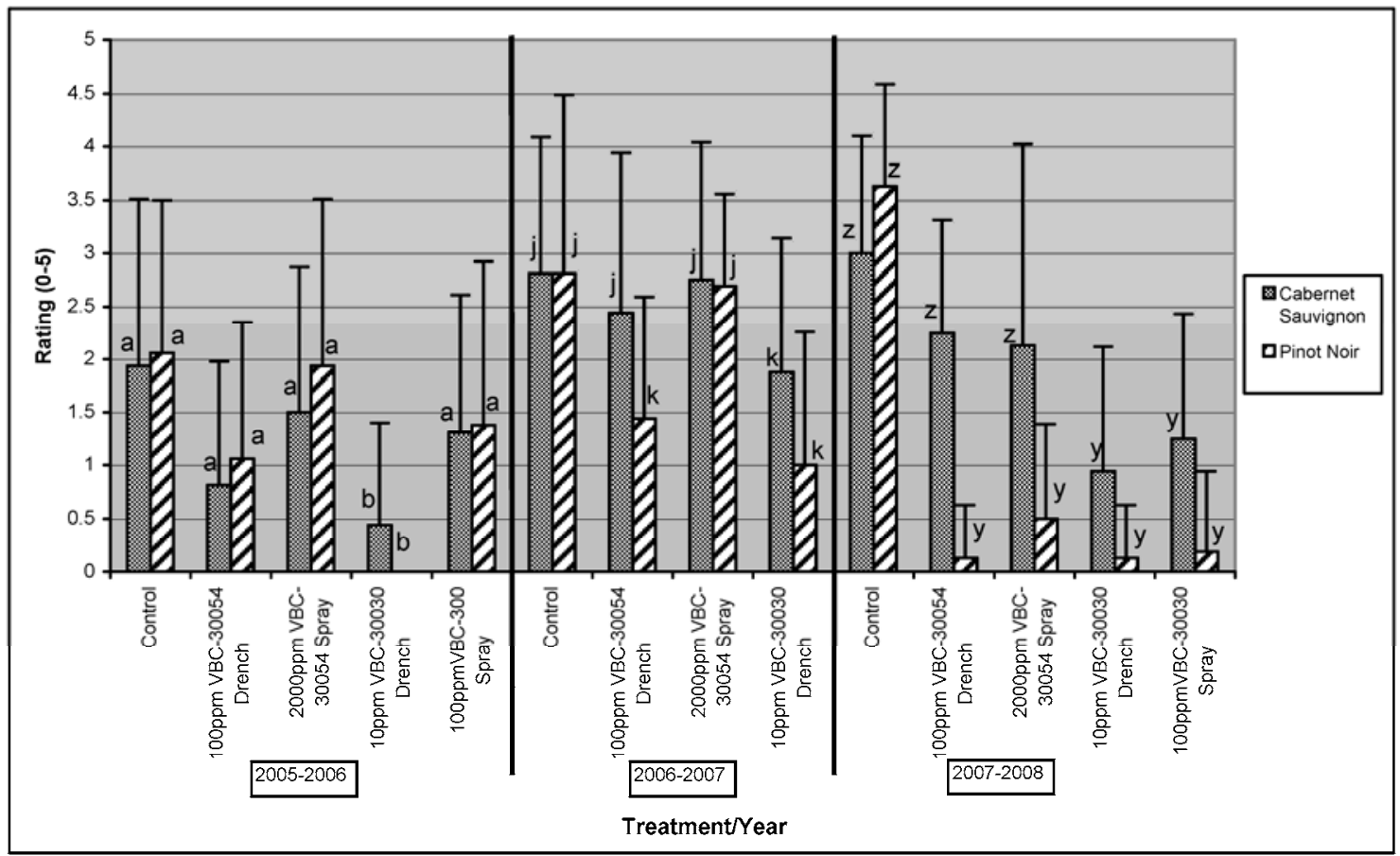

Fig. 2. Mean disease severity ratings of grapevines after abscisic acid treatment applications $(n=16)$. Each year and cultivar was analyzed separately. Significant by unpaired $t$ test with a two-tailed $P$ value $\leq 0.05$. 
increases plant susceptibility to several pathogens (2). For example, exogenous ABA application on chrysanthemum increased lesion expansion caused by Phytophthora cryptogea (2). Exogenous ABA application also results in increased root rot of tomato from P. parasitica (2). Lu et al. (26) found that, during the growing season, PD symptom development is associated with physiological and biochemical changes which include increased levels of ABA and salicylic acid. Plant growth regulators have been previously applied to grapevines as a possible control for PD. Hopkins (18) found that spring foliar applications of ABA applied on a 14-day schedule starting 7 days prior to inoculation with $X$. fastidiosa enhanced PD symptom development. This suggests that ABA applied during the spring and summer may actually increase PD symptoms rather than having a disease-curative effect as we found in fall ABA applications. Although the reasons that ABA increased PD symptoms during the growing season and fall application increased the rate of PD curing are unknown, one might speculate that the application of ABA, which is involved with causing and maintaining plant dormancy and inhibiting cell division and tissue growth might decrease plant defenses that would moderate the development of PD foliar symptoms during the growing season. Our finding that fall ABA application increased the concentration of phenolic compounds in xylem sap would also suggest that spring or summer application of ABA might also increase the synthesis of phenolic compounds that might inactivate plant proteins necessary for normal tissue or plant growth.

Our work shows that fall applications of ABA have a curing effect in PD-infected $V$. vinifera Pinot Noir grapevines grown in pots in the greenhouse and screenhouse. Interestingly, others also have shown that fall ABA applications induce disease resistance in several other plant-pathogen systems via unknown mechanisms $(3,45)$. Pretreatments of tobacco with ABA resulted in an increased resistance against Tobacco mosaic virus (10). Kuwabara et al. (24) elicited cold-shock proteins at $23^{\circ} \mathrm{C}$ in winter wheat with an exogenous application of ABA at $100 \mathrm{ppm}$. These ABA-treated plants elicited proteins that were able to inhibit growth of a winter wheat fungal pathogen. One of the proteins that was upregulated by ABA applications was a TLP (24). Expression of TLP was also induced by cold and by exogenous application of ABA $(24,30)$. TLP is a PR protein that is induced and accumulates in the apoplast (43) and exhibits antimicrobial activity in a number of plant-microbe interactions (24).
In our hands, the most effective fall ABA application was VBC30030 applied as a drench; however, some of the other applications, such as the foliar VBC-30030 application and the drench VBC-30054, also had PD-curing effects. Curing rates and reduction in disease rating in 2006-07 were lower compared with those observed in the 2005-06 and 2007-08 seasons (Figs. 1 and 2). This could possibly be due to a rain event that occurred a few hours after the 2006-07 ABA application, possibly diluting, washing off, or leaching out the applied ABA. Despite lower overall curing in all treatments compared with previous and subsequent years, the VBC-30030 drench treatment in Pinot Noir grapevines had more curing than the untreated control.

The drench treatments were more effective than the spray treatments at curing vines of PD. This could be due to the spray not effectively penetrating the leaves and entering the plant. Tween 20 was added to the spray mixture as directed but a more effective silicone-based surfactant may provide better penetration of ABA into the plant tissues.

The increase in total phenolic compounds in ABA-treated Pinot Noir correlated with the disease curing and symptom severity rating results. The vines with the highest total phenolics are also the vines that showed the highest curing percentages and lowest disease ratings (Figs. 1 and 3). The relationship between PD-curing ABA application and total phenolic content of xylem sap suggests additional research to better understand the molecular mechanism or mechanisms behind ABA-mediated PD reduction in Pinot Noir grapevines.

We noted an anomaly regarding the severity of winter cold temperatures and the amount of cold curing that occurred in the nontreated control vines. One would have expected that the amount of cold curing that occurred in nontreated, PD-affected control vines would have been greatest in 2006-07, which had the greatest number of hours of temperatures below $0^{\circ} \mathrm{C}$ (Table 2). However, only 15 to $20 \%$ of the control vines in 2006-07 recovered, whereas the amount of natural cold curing that occurred in nontreated, PDaffected vines in the warmer years of 2005-06 was 25 to $42 \%$ and, in 2007-08, it was 45 to $55 \%$. We thought that, perhaps, the onset or duration of cold temperatures for the 3 years might have been different. However, the first days of temperatures below $0^{\circ} \mathrm{C}$ occurred on 5 December in 2005-06, 1 December in 2006-07, and 25 November in 2007-08. Similarly, the last days that cold temperatures occurred were 20 February in 2005-06, 3 February in

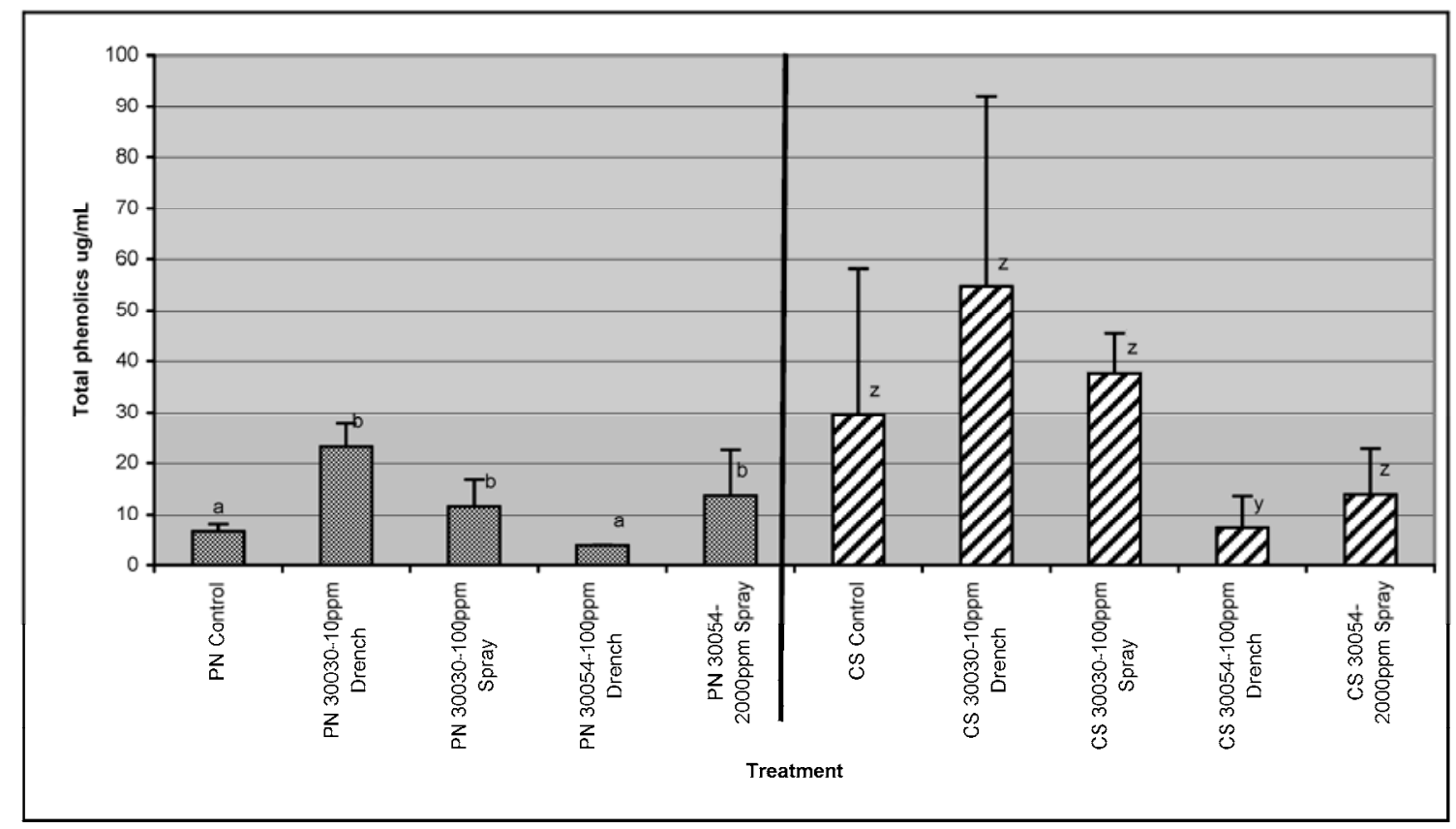

Fig. 3. Total phenolic compound content of xylem sap from 2007-08 abscisic-acid-treated vines. Significant by unpaired $t$ test with a two-tailed $P$ value $\leq 0.05(n=16)$. CS $=$ Cabernet Sauvignon and PN = Pinot Noir. 
2006-07, and 21 January in 2007-08. Thus, there was no large difference in either the onset or duration of chilling periods for the 3 years of the study. The same grapevine cultivar and rootstock, obtained from the same nursery and grown in the same manner, were used throughout the study. Thus, the reason for the comparatively low rate of curing that occurred during the coldest year (2006-07) remains unknown.

ABA application for the treatment of PD-infected vines could potentially provide growers in areas with moderate winters and persistent PD with an additional tool to control disease in their vines. Further tests with mature field vines are required to determine the usefulness of fall ABA applications for control of PD in commercial vineyards. This control method will not prevent vines from being inoculated by $X$. fastidiosa-infectious insect vectors. In addition, the presence of $X$. fastidios $a$ in other plant hosts means that the bacteria will continue to be present in the environment. Grapevines in those environments will continue to experience disease pressure from $X$. fastidiosa, and $X$. fastidiosa-infected vines would need annual fall applications to manage new infections, should field testing of ABA application prove efficacious.

\section{Acknowledgments}

This research was supported by grants from the CDFA Pierce's Disease Control Program and Valent Biosciences. ABA was provided by Valent Biosciences. Grapevines were generously donated by Sunridge Nursery. We thank S. Abrams at the National Research Council Canada for ABA information and guidance.

\section{Literature Cited}

1. Blanchard, R. O., and Tattar, T. A.1987. Field and Laboratory Guide to Tree Pathology. Academic Press, New York.

2. Bostock, R. M. 1999. Signal conflicts and synergies in induced resistance to multiple attackers. Physiol. Mol. Plant Pathol. 55:99-109.

3. Bostock, R. M. 2005. Signal crosstalk and induced resistance: straddling the line between cost and benefit. Annu. Rev. Phytopathol. 43:545-580.

4. Bravo, L. A., Zuniga, G. E., Alberdi, M., and Carcuera, L. S. 1998. The role of ABA in freezing tolerance and cold acclimation in barley. Physiol. Plant. 103:17-23.

5. Chen, H. H., Li, P. H., and Brenner, M. L. 1983. Involvement of abscisic acid in potato cold acclimation. Plant Physiol. 71:362-365.

6. Dave, R. S., and Mitra, R. K.. 1998. A low temperature induced apoplastic protein isolated from Arachis hypogaea. Phytochemistry 49:2207-2213.

7. Davis, M. J., Purcell, A. H., and Thomson, S. V. 1980. Isolation media for the Pierce's Disease bacterium. Phytopathology 70:425-429.

8. Dihazi, A., Jaiti, F., Zouine, J., El Hassni, M., and El Hadrami, I. 2003. Effect of salicylic acid on phenolic compounds related to date palm resistance to Fusarium oxysporum f. sp. albedinis. Phytopathol. Mediterr. 42:9-16.

9. Feil, H. 2002. Effect of sub-freezing temperature on the survival of Xylella fastidiosa in vitro and in plants. Ph.D. dissertation, University of California, Berkeley.

10. Fraser, R. S. S. 1982. Are 'pathogenesis-related' proteins involved in acquired systemic resistance of tobacco plants to tobacco mosaic virus? J. Gen. Virol. 58:305-313.

11. Freitag, J. H. 1951. Host range of Pierce's disease virus of grapes as determined by insect transmission. Phytopathology 41:920-934.

12. Fry, S. M., and Milholland, R. D. 1990. Multiplication and translocation of Xylella-fastidiosa in petioles and stems of grapevine resistant, tolerant, and susceptible to Pierce's disease. Phytopathology 80:61-65.

13. Guilhabert, M. R., and Kirkpatrick, B. C. 2005. Identification of Xylella fastidiosa avirulence genes: hemagglutinin adhesions contribute to X. fastidiosa biofilm maturation and colonization and attenuate virulence. Mol. Plant-Microbe Interact. 18:856-868.

14. Guy, C. L. 1990. Cold acclimation and freezing stress tolerance: role of protein metabolism. Annu. Rev. Plant Physiol. 41:187-223.

15. Hill, B. L., and Purcell, A. H. 1995. Multiplication and movement of Xylella fastidiosa within grapevine and four other plants. Phytopathology 85:1368-1372.

16. Hon, W. C., Griffith, M., Mlynarz, A., Kwok, Y. C., and Yang, D. S. C. 1995. Antifreeze proteins in winter rye are similar to pathogenesis-related proteins. Plant Physiol. 109:879-889.

17. Hopkins, D. L. 1980. Use of the pin-prick inoculation technique to demonstrate the variability in virulence of the Pierce's disease bacterium. Pages 77-180 in: Proc. Seventh Int. Congr. Viruses of Grapevine (ICVG). Niagara Falls, Canada.

18. Hopkins, D. L. 1985. Effects of plant growth regulators on PD symptoms in grapevine. Plant Dis. 69:944-946.

19. Hopkins, D. L. 1989. Xylella-fastidiosa: xylem-limited bacterial pathogen of plants. Annu. Rev. Phytopathol. 27:271-290.

20. Hopkins, D. L., and Adlerz, W. C. 1988. Natural hosts of Xylella-fastidiosa in Florida USA. Plant Dis. 72:429-431.

21. Hopkins, D. L., and Purcell, A. H. 2002. Xylella fastidiosa: cause of
Pierce's disease of grapevine and other emergent diseases. Plant Dis. 86:1056-1065.

22. Hopkins, D. L., and Thompson, C. M. 1984. Seasonal concentration of the Pierce's disease bacterium in cultivars Carlos and Welder muscadine grapes Vitis rotundifolia compared with cultivar Schuyler bunch grape Vitis labrusca. Hortscience 19:419-420.

23. Jiang, Y., and Joyce, D. C. 2003. ABA effects on ethelene production, PAL activity, anthocyanin and phenolic contents of strawberry fruit. Plant Growth Regul. 39:171-174.

24. Kuwabara, C., Takezawa, D., Shimada, T., Hamada, T., Fujikawa, S., and Arakawa, K. 2002. Abscisic acid and cold-induced thaumatin-like protein in winter wheat has an antifungal activity against snow mold, Microdochium nivali. Physiol. Plant. 115:101-110.

25. Lee, S. M., Dong Hyun, D., Lee, C. H., and Kim, S. B. 1996. Effects of ABA and kinetin treatments on the coloration and quality of 'Campbell Early' and 'Black Olympia' grapes. J. Korean Soc. Hortic. Sci. 37:263-268.

26. Lu, J., Xu, X., Ren, Z, Yun, H,, and Liu, X. 2003. Interaction between the pathogen and host plants during the Pierce's disease development of grapevines. HortScience 38:687.

27. Martin, J. A., Solla, A., Rosario Domingues, M., Coimbra, M. A., and Gil, L. 2008. Exogenous phenol increase resistance of Ulmus minor to Dutch elm disease through formation of suberin-like compounds on xylem tissues. Environ. Exp. Bot. 64:97-104.

28. McElrone, A. J., Sherald, J. L., and Forseth, I. N. 2001. Effects of water stress on symptomatology and growth of Parthenocissus quinqefolia infected by Xylella fastidiosa. Plant Dis. 85:1160-1164.

29. McElrone, A. J., Sherald, J. L., and Forseth, I. N. 2003. Interactive effects of water stress and xylem-limited bacterial infection on the water relations of a host vine. J. Exp. Bot. 54:419-430.

30. Meyer, M. M. 2010. The effects of cold temperature on Xylella fastidiosainfected Vitis vinifera grapevine. Ph.D. thesis, University of California, Davis.

31. Minsavage, G. V., Thompson, C. M., Hopkins, D. L., Leite, R. M. V. B. C., and Stall, R. E. 1994. Development of a polymerase chain reaction protocol for detection of Xylella fastidiosa in plant tissue. Phytopathology 84:456-461.

32. Oh, S., Kim, J. A., Jeon, H., Park, J. C., Koh, Y. J., Hur, H., and Hur, J. 2008. Antifungal activity of eucalyptus-derived phenolics against postharvest pathogens of kiwifruits. Plant Pathol. J. 24:322-327.

33. Purcell, A. H. 1977. Cold therapy of Pierce's disease grapevines. Plant Dis. Rep. 61:514-518.

34. Purcell, A. H. 1980. Environmental therapy for Pierce's disease of grapevines. Plant Dis. 64:388-390.

35. Purcell, A. H., and Saunders, S. R. 1999. Fate of Pierce's disease strains of Xylella fastidiosa in common riparian plants in California. Plant Dis. 83:825-830.

36. Raju, B. C., and Goheen, A. C. 1981. Relative sensitivity of selected grapevine Vitis vinifera cultivars to Pierce's disease bacterial inoculations. Am. J. Enol. Vitic. 32:155-158.

37. Raju, B. C., and Wells, J. M. 1986. Diseases caused by fastidious xylemlimited bacteria and strategies for management. Plant Dis. 70:182-186.

38. Rudrappa, T., and Bais, H. P. 2008. Curcumin, a known phenolic from Curcuma longa, attenuates the virulence of Pseudomonas aeruginosa PAO1 in whole plant and animal pathogenicity models. J. Agric. Food Chem. 56:1955-1962.

39. Sari, E., Etebarian, R. H., and Aminian, H. 2008. Effects of Pseudomonas fluorescens $\mathrm{CHA} 0$ on the resistance of wheat seedling roots to the take-all fungus Gaeumannomyces graminis var. tritici. Plant Prod. Sci. 11:298-306.

40. Sarma, B. K., Basha, S. A., Singh, D. P., and Singh, U. P. 2007. Use of nonconventional chemicals as an alternative approach to protect chickpea ( $\mathrm{Ci}$ cer arietinum) from Sclerotinia stem rot. Crop Prot. 26:1042-1048.

41. Singleton, V. L., Orthofer, R., and Lamuela-Raventos, R. M. 1999. Analysis of total phenols and other oxidation substrates and antioxidants by means of Folin-Ciocalteu reagent. Methods Enzymol. 299:152-178.

42. Smart, C. D., Hendson, M., Guilhabert, M. R., Saunders, S., Friebertshauser, G., Purcell, A. H., and Kirkpatrick, B. C. 1998. Seasonal detection of Xylella fastidiosa in grapevines with culture, ELISA and PCR. (Abstr.) Phytopathology. 88:S83.

43. Stintzi, A., Heitz, T., Prasad, V., Wiedemann-Merdinoglu, S., Kauffmann, S., Geoffroy, P., Legrand, M., and Fritig, B. 1993. Plant 'pathogenesisrelated' proteins and their role in defense against pathogens. Biochimie 75:687-706.

44. Thomashow, M. F. 1998. Role of cold responsive genes in plant freezing tolerance. Plant Physiol. 118:1-7.

45. Ton, J., and Mauch-Mani, B. 2004. $\beta$-Amino-butyric acid-induced resistance against necrotrophic pathogens is based on ABA-dependent priming for callose. Plant J. 38:119-130.

46. Waterhouse, A. L. 2002. Determination of total phenolics. Units I.1.1.1 to I1.1.8 in: Current Protocols in Food Analytical Chemistry. R. E. Wrolstad, ed. John Wiley \& Sons, New York,

47. Zhang, J., Jia, W., and Zhang, D. 1997. Export and metabolism of xylemdelivered $\mathrm{ABA}$ in attached maize leaves under different transpirational fluxes and xylem ABA concentration. J. Exp. Bot. 48:1557-1564.

48. Zhang, J., and Davies, W. J. 1990. Does ABA in xylem control the rate of leaf growth in soil-dried maize and sunflower plants/ J. Exp. Bot. 41:1125-1132. 